\title{
Freedom in Education
}

$I^{2}$ am a formerly incarcerated man from New York City. Gaining a better education while incarcerated was very transformative; it gave me hope and it served as a great filler of idle time, which prison has in abundance. Allow me to begin by describing my background in order to give you a better understanding of my educational struggles. My early life experiences played a role in my lack of productivity and illegal activity, and to me eventually becoming a detriment to society. In my experience, incarcerated individuals often suffer from low self-esteem, low confidence, have many learning challenges, and lack higher education due to their poor socioeconomic standing and environment.

I have struggled with education for a great deal of my life. Before I was born, doctors believed that I would go through life with some sort of physical disability or mental abnormality because of the circumstances that surrounded my conception and birth. While I am currently in pristine physical and mental health, this is not what my family expected. Throughout my childhood, there were ill-conceived preconceptions about my abilities given that my biological parents met each other in the psychiatric unit of the Rockland county medical facility where they were taking psychotropic medication. When the medical staff became aware that my mother was pregnant, they informed her that it would be best for me to be aborted. This preconceived notion that I would suffer from mental challenges labelled me before I was able to show my potential. As a result, I was treated as if I was slow. These views invaded my mind, causing me to lose self-esteem and to despise education as I assumed there was no hope for me. As time went on, I fell behind in my intellectual growth and decided to leave school and turn to the streets.

By leaving school, I felt that I could at least avoid the embarrassment of being so far behind my peers. Hanging out in my neighbourhood instead of going to class became normal. As time went on, out of boredom I began to cause mischief such as doing drugs, trespassing and fighting. Slowly, the negativity progressed and I acquired a criminal lifestyle, along with a severe drug addiction. Caught in the grips of addiction I began committing robberies, using and selling hard drugs, and repeatedly coming into conflict with the law. I was nothing more than a detriment to my community. Feeling that I had no other options, since I could not read, crime seemed to be the only way of life for me. 
I was illiterate in almost every aspect of basic education and I seemed to have little hope. It was not until I reached the age of nineteen that I began to make an effort to progress, weary with the inability to read and write at a fifth grade level. I poured all my efforts into teaching myself by reading everything in sight, along with utilizing a learning method I devised that is vocabulary based and by listening intently to others and how they formed sentences. By learning more about speech and memorizing verbal structure, I was able to use the simple words I could decipher. Using this path, I excelled profoundly. The one thing I lacked was self-confidence and the desire to stray from the life I had grown accustomed too. Even though my reading advanced, I could not escape the hopelessness that was my life and everything that surrounded it poverty, drugs, and violence. I could not see light anywhere and the only thing that I knew to be true was that I would be unsuccessful. Being that I still did not believe in myself, I reverted back to the street life of drugs and everything that came along with that life. My problems worsened and I found myself in legal trouble quite often.

Arrest after arrest I eventually found myself serving time in state prison. The time I spent at Marcy correctional facility had a very transformative effect because of the availability of prison education that was unavailable at previous facilities. I was intrigued by a book club at the facility that was run by a professor from Hamilton College. The three groups varied from philosophy, foreign literature and art. At first I hesitated to speak in the groups, but as time went on, I began to involve myself. It was so empowering to have people value my views and opinions of the readings. In those groups I found something I had been longing for. Developing the ability to express my thoughts and ideas gave me a great sense of self-worth and purpose. This opportunity assisted greatly in cultivating a tree of knowledge within me that bore fruit of science, history, poetry and art. I wanted more - I wanted to attend college formally.

It was not long before I was transferred to another prison, but I did not lose the ambition and desire for intellectual growth that I gained from attending those first college classes. I was first transferred to Lakeview, which is a mock military program for incarcerated men and women of different age groups. At one point, the librarian who facilitated the transitional class asked us what we wanted to do in the future. I told him how my sole ambition was to attend college one day. His response to me 
was that this was an unrealistic goal and that I should set my mind on working at Home Depot. I could not accept that as my only option and would not allow his perspective or anyone else's who thinks less of my abilities to get in the way of accomplishing my dreams. It was not until I arrived at Wallkill correctional facility that the opportunity presented itself. As soon as I arrived, I learned that New York University (NYU) would be holding a prison education program in the facility. At that moment I said to myself, "I'm going to be in that program". But first, I needed to get my GED so I put all my energy into studying. Not only was I studying for my GED, I also involved myself in the Prisoners for AIDS Counseling and Education program (PACE).

In the PACE program I learned how to facilitate classes to educate other prisoners on HIV transmission and prevention. I made the most of every opportunity I had and the PACE program offered me the chance to gain more education. I could never have imagined what I would learn from that program. While running the PACE program and studying for the GED test, things fell into place quickly. Within three months, all of my efforts began to show. I scored exceptionally high on the pre-test, which increased my confidence especially since studying is not easy in prison. There were many obstacles I had to overcome dealing with other prisoners and officers, some of who frowned upon the success of prisoners. It is extremely difficult to navigate around all of the negativity in prison, the threat of danger, along with trying to maintain my health with few provisions and within the poor quality conditions of the environment in which we live. I did everything in my power to overcome these challenges, but separating myself from the chaos and pessimism of prison life was no easy task. That tenacity and determination paid off and my dreams were clearly becoming tangible.

After receiving my GED I immediately applied to NYU. Within no time, I received my letter of acceptance and I was overjoyed. Looking back at my life, I remembered where I came from and what it took for me to get to this moment. I felt ready for any battle. To prepare myself, I read as much as I could and devoted my time to studying. When I was in my housing unit and around the compound, I surrounded myself with positive individuals who were involved in prison education programs and others who sought to utilize their time as constructively as they could. We would converse about many things like books and articles we had 
read, and we had debates on social, economic and scientific matters. We helped each other with writing assignments, gave our perspectives on close readings, but mostly expressed to each other our goals and how we planned to achieve them, and advised one another by telling stories about our past decisions that did not work out so well. Having a group of people who added to what I was learning and who were willing to assist me to facilitate my intellectual growth gave me the positive reassurance I needed to continue to move ahead. I was very nervous my first day in class, but I was not alone. Many of my peers, some of whom had not been in a classroom setting for quite some time, all felt the same way. We found strength in unity, pushing each other as hard as we could in order to make sure that everybody was on the right track and keeping focused.

The first class that I took was a writing course and the main research topic was Herman Melville's Benito Cereno. That course gave me a better understanding of history - a history that I did not know existed until then. I did a lot of my research on maroon culture; a group of African men and women who fled slavery, vanishing into the most inhospitable regions across South America where they formed their own communities. This course assisted me to greatly improve my writing capabilities. My professor Elaine Freedgood was an exceptional educator and did all she could to cultivate educational growth in her class. She and the other professors were truly invested in us, showing us an extraordinary amount of care, devotion, and tenacity to help us overcome the opposition that was put forth by some employees of the correctional facility. It was evident that our educational advancement was in the forefront of the professors' minds, for which I am truly grateful.

The long hours I put in studying in my cell were well worth it. At times, I felt broken while facilitating HIV/AIDS education classes and exhausted staying up long hours into the night to structure and write papers. It was extremely taxing, but I kept in mind that this was something I needed to get used to if I wanted to be successful and continue on this path upon my release. I remember when Professor Freedgood called me and two other students to ask if we would agree to become class tutors. I could not believe it - me, someone who in the past struggled so much with education was now going to help other students. Deep down I knew what I wanted to do. I wanted to give back to others what I had acquired myself. On one occasion a fellow classmate of mine came to my cell to ask me for help and he asked how education came so easily to me. I told 
him that it does not and that I struggle very much every day. I told him that I sacrifice long hours, dedicate myself completely to the work, and that I always remind myself what I am fighting for in order to keep my goals and ambition in the forefront of my mind.

As time progressed, I continued to take advantage of every opportunity I could find. I next applied to the Justice in Education Scholars Program where I was able to take a humanities course at Columbia University. I was grateful to have gained a greater self-confidence when I was accepted and I will be taking that course this summer. Earning an education while in prison transformed me in a deeply profound way and has helped to make my transition back into society a lot smoother. Now I have goals, I have something to look forward to and I know that there are so many other things I can do with my life. I can say that it is because of prison education that I see myself, as well as other men and women who are formerly incarcerated, as benefits instead of as detriments to society. In prison, there are so many men and women who have great minds and are capable of many things. It is through education that they will be able to realize their potential and progress to a brighter future. From my experience, I have found that many incarcerated people lack fundamental educational opportunities and suffer from low confidence and self-esteem. The better educated we are, the more likely we are to be successful members of our communities and the world.

\section{ABOUT THE AUTHOR}

Ismael Bonano was born and raised in New York City. At 28 years old, he currently works as a construction worker and resides in a shelter in Brooklyn, New York. He spent five years in prison and in that time he received his GED diploma and other certifications, including HIV/AIDS counseling and education. Since his release, he has had the opportunity to do fellowships with Columbia University and New York University. He is a founding member of Re-emergent Theater, performing arts group geared toward incarcerated individuals transitioning back into society. He also acts as a national councilman for Incarcerated Nation, a non-profit organization that helps raise awareness concerning prison issues. He is an avid collector of comic books, as well as graphic novels. In his down time, he always seeks new avenues of educational exploration including, but not limited to, self-education. His goal is to obtain a degree in environmental sciences in order to become a wildlife conservationist. 